\title{
3-(4-Bromobenzoyl)prop-2-enoic acid as Precursor in Synthesis of Some Important Heterocyclic Compounds
}

\author{
Maher A. El-Hashash, Sameh A. Rizk*, Ebtessam A. Ahmed
}

Chemistry Department, Faculty of Science, Ain Shams University, Abbassia, Cairo, Egypt

\begin{abstract}
The present work deals with the generation and synthesis of different heterocycles such as 2-pyrimidine thione, pyrane, pyridine and phthalazinone derivative via the treatment of 3-(4-bromobenzoyl)prop-2-enoic acid with thiourea, ethylcyanoacetate malononitrile\& acetylacetone in presence of amm.acetate and/or piperidine respectively.Additionally, utility of 2-amino-3-cyano-4-carboxy-6-(4-bromophenyl)3,4-dihydropyridine (4) as a key starting material to synthesize some important heterocycles include fused pyrido-pyrimidine,fused pyrido- pyridazinopyrimidine and interesting diheterocyclic amines.
\end{abstract}

Keywords 3-Aroyl prop-2-enoic acid,pyrrole,furan, Pyridone, Ethylnicotinate, pyrane, phthalazinone, 2-pyrimidine thione,pyridopyrimidine,pyridazino-pyrimidine

\section{Introduction}

It has been reported [1,2] that -aroylacrylic acids were used as inhibitors of phospholipase from snake venom and from procaine pancreas, also they have antibacterial activities $[3,4]$, which prevented the growth of staphylococcus aureus, beside their anti-proliferative [5] action against human cervix carcinoma. Recently [6,7] 3-(4-acetamido)andlor 4-chloro benzoyl prop-2-enoic acid were used in the synthesis of some heterocyclic compounds. Hence, keeping these reports in view and continuation of our search for 3-aroyl prop-2-enoic acid derivatives[8-13], the present work deals with the study of behaviour of 3-(4- bromobenzoyl)prop-2-enoic acid towards the action of different nucleophilic species including carbon, nitrogen nucleophiles and the utility some of the reaction products in heterocyclic synthesis, hoping to get new compounds of anticipated biological activities.

\section{Results \& Discussion}

Addition of ethyl cyanoacetate on 3-(4-bromobenzoyl)acrylic acid (1) in the presence of ammonium acetate yielded a mixture of ethyl-2-amino-4-carboxy-6-(4-bromophenyl)nicotinate (2) and 2-oxo-3-cyano--6-(4-bromophenyl)pyridine-4-carboxylic acid (3), whereas the compounds 2 and 3 can be explained[14]. Also, in the present investigation, similar treatment of 1 with malononitrile in the presence of

* Corresponding author:

Samehrizk2006@gmail.com (Sameh A. Rizk)

Published online at http://journal.sapub.org/chemistry

Copyright (C 2012 Scientific \& Academic Publishing. All Rights Reserved ammonium acetate in boiling butanol gave 2-amino-3cyano-6-(4-bromo)phenyl 3,4-dihydropyridine 4-carboxylic acid (4). The structure of 1:1 adduct 4 obtained by base catalyzed Michael addition of malononitrile to acid 1 is elucidated by studying their spectroscopic properties. The mass spectrum of 4 shows the correct molecular ion peak. On the other hand,when compound 1 was treated with malononitrile in the presence of piperidine in boiling ethanol yielded 2-amino-3-cyano-6-(4-bromophenyl)-pyrane 4-carboxylic acid (5). (Scheme 1).

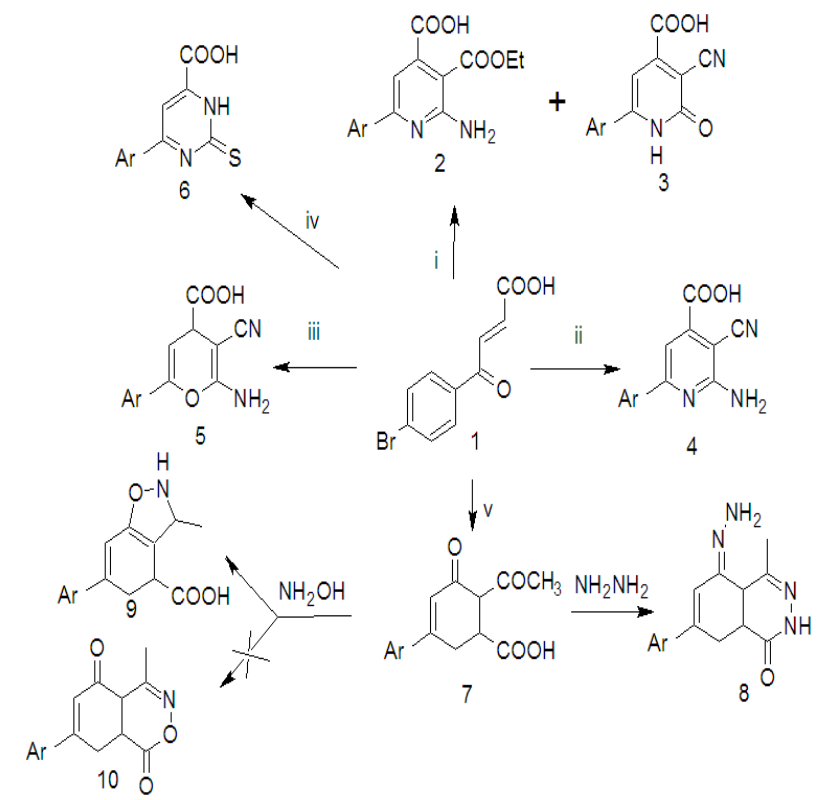

$$
\begin{array}{ccc}
\mathrm{i}=\mathrm{CH}_{2}(\mathrm{CN}) \mathrm{COOEt} / \mathrm{CH}_{3} \mathrm{COONH}_{4} \quad \mathrm{ii}=\mathrm{CH}_{2}(\mathrm{CN})_{2} / \mathrm{CH}_{3} \mathrm{COONH}_{4} \quad \mathrm{iii}=\mathrm{CH}_{2}(\mathrm{CN})_{2} / \text { pip: } \\
\text { iv }=\mathrm{CS}\left(\mathrm{NH}_{2}\right)_{2} / \mathrm{EtONa} \quad \mathrm{v}=\left(\mathrm{CH}_{3} \mathrm{CO}\right)_{2} \mathrm{CH}_{2} / \mathrm{MeONa} & \mathrm{Ar}=\mathrm{C}_{6} \mathrm{H}_{4}(4 \mathrm{Br}) \\
\text { Scheme1 } &
\end{array}
$$


The pyrimidines and their ring-fused derivatives are one of the most active classes of compounds, possessing a wide spectrum of biological activity[15]. They are known as heterocyclic core of the nucleic acid bases. These ring systems are often incorporated into drugs designed for anticancer[16,17], antiviral[18], Antihypertensive[19], analgesic [20], antipyretic[21], anti-inflammatory[22], anti- psoriasis[23] agents. Some of them are active on the blood circulatory system[24] and can stimulate the skin regeneration and increase the efficacy of antibiotic therapy of Staphylococcus and Proteus infected wounds[25]. The authors sought to investigate the behavior of 1 with thiourea in boiling ethanol in the presence of sodium ethoxide under Michael reaction condition afforded 4-(4-bromophenyl)-6-carboxypyrimidin$2(1 \mathrm{H})$ thione (6). (Scheme 1). The structure of compound 6 is confirmed by correct microanalytical data and also by spectral evidence. $\mathrm{C}=\mathrm{O}$ at $1676 \mathrm{~cm}^{-1}$. The lower absorption for carbonyl group is due to formation of conjugated double bond results from dehydrogenation i.e formation of $\alpha, \beta$ unsaturated system. The EI-MS shows the molecular ion peak at $\mathrm{m} / \mathrm{e} 312$ and 310 corresponding to $(\mathrm{M}+2)^{+}\left(\mathrm{M}^{+}\right)$. respectively Morever, Reaction of 3-(4-bromo) benzoyl acrylic acid (1) with acetylactone in refluxing methanol in the presence of sodium methoxide(Michael condition) afforded the 3- (4- bromophenyl)- 5- carboxy- 6-acetylcyclohexen-1- one (7). This substituted cyclohexenone derivative 7 is considered as a key starting material for divers of some interesting heterocyclic compounds. The structure of compound 7 is deduced from its micro analytical and spectral data. The presence of the intramolecular hydrogen bond (chelated form) cause lowering $\mathrm{C}=\mathrm{O}$ as expected. Further support for the proposed structure of 7 was gained from the EI-MS spectrum that the m/e 320,318 $\left(\mathrm{M}+2, \mathrm{M}^{+}-\mathrm{H}_{2} \mathrm{O}\right)$. The derivatives of naphthoheterocyclic have attracted the attention of many organic chemists owing to their well pronounced activities such as anticancer[26], antifungal, cytotoxic[27] and in the treatment of metabolic disorders[28]. Reaction of acetylcyclohexenone derivative 7 with hydrazine hydrate in boiling ethanol yielded $1(2 \mathrm{H})$ phthalazinone derivative 8 . Condensation takes place firstly with reactive acetyl carbonyl followed by ring closure then formation of the corresponding hydrazone. The structure of compound 8 is substantiated by spectroscopic tools. In EI-MS exhibits molecular ion peaks $\mathrm{m} / \mathrm{e}(347,349$ 18.2\%) beside some of abundant peaks.

Reaction of 7 with hydroxylamine hydrochloride in boiling pyridine gave the benzisoxazole derivative 9 and not 4H-2,3-benzoxazin-4-one 10 which less thermodynamically stable than 9 . The structure of compound 9 is confirmed by correct micro analytical data and also by spectral evidence.

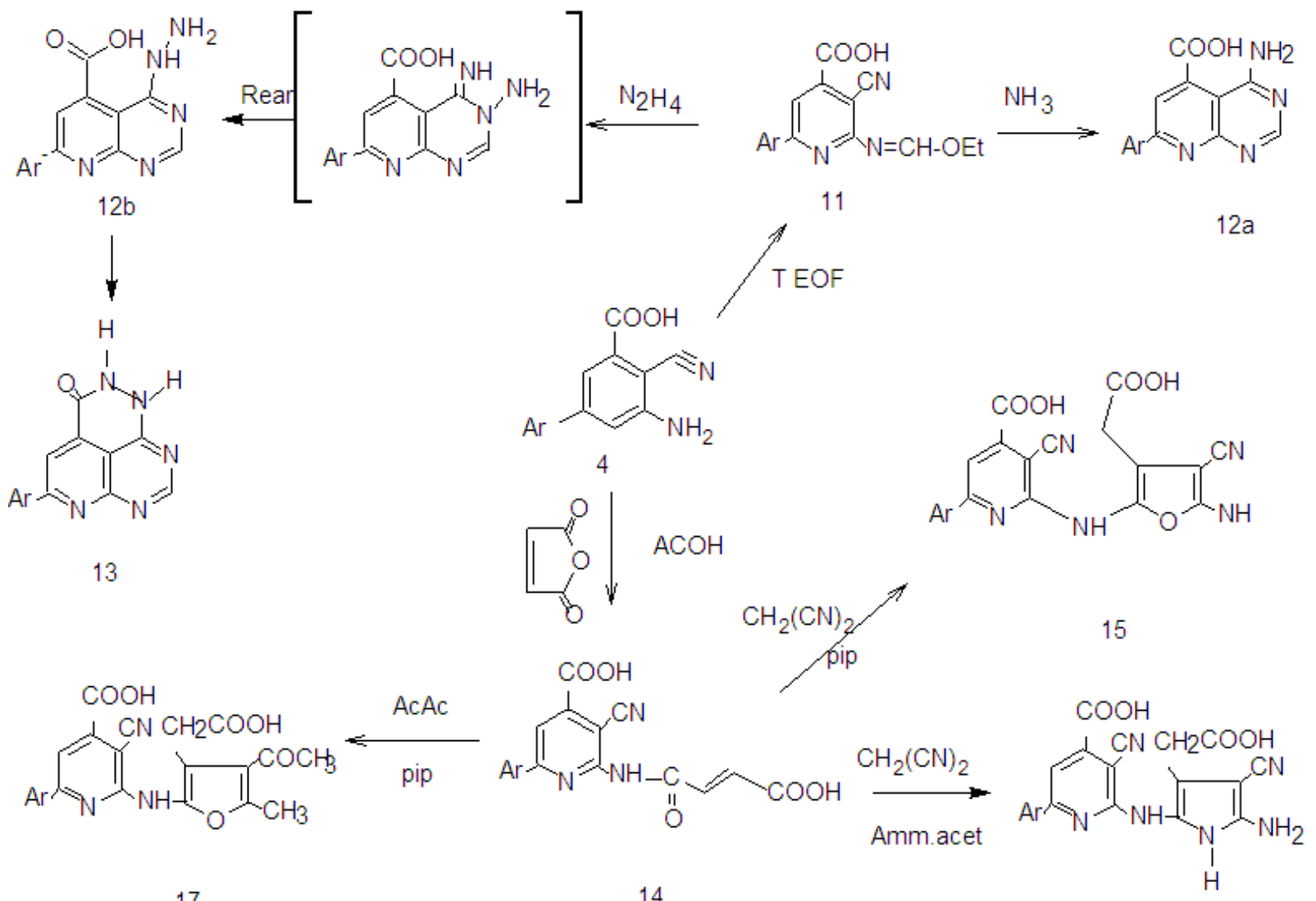


Refluxing of 4 with neat triethyl-orthoformate (TEOF) [29-31] afforded 6-(4-bromophenyl)-3-cyano-2- (ethoxymethyleneamino) pyridine-4-carboxylic acid 11.Its IR displayed an absorption bands at 1645,1725,2220 and 3410 $\mathrm{cm}^{-1}$ attributable to $\mathrm{C}=\mathrm{N}, \mathrm{C}=\mathrm{O}, \mathrm{CN}$. $\mathrm{OH}$. and showed no absorption frequency in the NH region. The H-NMR spectrum of compound 11 showed singlet signal of the azamethine proton $(\mathrm{N}=\mathrm{CH})$ at $\delta 6.76$, triplet at $\delta 1.1$ and quartet signal at $\delta 4.3$ assigned for $(\mathrm{OCH} 2 \mathrm{CH} 3)$.Ammonolysis of compound 11 gave 4-amino7-(4-bromophenyl) pyridine [2,3-d] pyrimidine-5-carboxylic acid 12.structure of 12 was inferred from correct analytical data and H-NMR exhibited exchangeable singlet at 8.23 assigned for $(\mathrm{NH} 2)$ at the pyrimidine ring and broad exchangeable singlet at 11.6 correlated with $(\mathrm{COOH})$ proton at the pyridine ring. The reaction involved nucleophilic substitution on the unsaturated carbon atom followed by ring closure to afford 12 . Inteaction of compound 11 with hydrazine hydrate[32] in boiling ethanol yielded 5-(4-bromophenyl)-1,2,3-trihydro1,2,6,7,9-pentaza-phenalen-3(3H)-one 13 , without isolation the hydrazino derivative $12 \mathrm{~b}$. This could be explained by the formation of the imino derivative first, which the presence of a base (hydrazine hydrate) underwent a Dimroth rearrangement[33-35] to give the thermodynamically more stable hydrazine derivative which underwent ring closure and yielded the desired product 13 . IR spectrum of compound 13 exhibited strong absorption bands at 1615,1655and 3325 $\mathrm{cm}^{-1}$ corresponding to $\mathrm{C}=\mathrm{N}, v C=O$ (amide) and devoid $v \mathrm{NH}$ any band at 2220.The H-NMR spectrum revealed exchangeable two singlet signals at 9.35 and $5.21 \mathrm{ppm}$ attributable to the protons of $(\mathrm{CONH})$ and $(\mathrm{CONHNH})$ at the pyridazinone ring,and devoid any exchangeable $(\mathrm{OH})$.The $\mathrm{N}$-cyclic maleamic acid 14[36,37] has been synthesized via interaction of 4 with maleic anhydride in refluxing acetic acid (Scheme-2).The N-cyclic maleamic acid was constructed such that due to the ring-cleaved structure of maleic anhydride

$(-\mathrm{COCH}=\mathrm{CH}-\mathrm{COOH})$ that bonded to the amino group (NH2) of the starting N-cyclic amine via a maleamide bond (-NH-CO-). The structure of the N-cyclic maleamic acid 14 has confirmed by analytical and spectral analyses. IR spectrum of compound 14 exhibited strong absorption bands at $1634,1719,2209,3217,3347$ and $3445 \mathrm{~cm}^{-1}$ attributable to $v C=O$ (amide), $v \mathrm{C}=\mathrm{O}$ (carboxyl), $v \mathrm{CN}, v \mathrm{NH}$ and $v \mathrm{OH}$ respectively. Interaction of the compound 14 with malononitrile in the presence of piperidine as catalyst afforded 2-[5-amino-3-(carboxymethyl)-4-cyano-furan-2-ylamino]-6 -(4-bromophenyl)-3- cyano-pyridine-4-carboxylic acid 15 . IR spectrum of compound 15 revealed strong absorption bands at $1629,1719,2207,3220,3372$ and 3447 due to $v C=N$, $v C=O, v C N$ and $v \mathrm{NH}$ and/or $v \mathrm{OH}$ respectively. Refluxing compound 14 with malononitrile in the presence of ammonium acetate [38] afforded 2- [5-amino-3-( carboxymethyl)-4-cyano-lH-pyrrol-2-ylamino)]-6-( 4-bromophenyl) - 3-cyano-pyridine-4-carboxylic acid 16. The reactions take place via Michael addition followed by ring closure to give the desire products 15,16 respectively. Structure of com- pound 16 was inferred from microanalytical and spectral data.Its IR spectrum revealed strong absorption bands at $1632,1720,2210,3217,3354$ and $3451 \mathrm{~cm}^{-1}$ attributable to. $v C=N, v C=O, v C N, v \mathrm{NH}$ and/or $v \mathrm{OH}$ respectively. The IH-NMRspectrum showed exchangeable (NH2) as well as singlet consistent with protons of methylene group of $\left(\mathrm{CH}_{2} \mathrm{COOH}\right)$. When compound 14 was allowed to react with acetylacetone in the presence of piperidine as catalyst, it yielded 2-[4-acetyl-3-carboxy methyl)-5-methyl furan-2-yl amino]-6-(4-bromophenyl)- 3- cyanopyridine- 4- carboxylic acid 17. The IR spectrum of 17 revealed strong absorption bands at $1631,1720,2210,3213,3347$ and $3448 \mathrm{~cm}^{-1}$ attributable to $v C=N, v C=O, v C N, v \mathrm{NH}$, and $v \mathrm{OH}$ respectively. The IH-NMR spectrum exhibited absorption signals correlated with the $(\mathrm{CH} 3),\left(\mathrm{COCH}_{3}\right)$ and $\left(\mathrm{CH}_{2} \mathrm{COOH}\right)$ protons. El-MS exhibited $\mathrm{m} / \mathrm{z} 455$ and 453 corresponding to ([M+2] and $\mathrm{M}-\mathrm{CO}_{2}$ ) respectively.

\section{Conclusions}

The proposed procedure is an easy and inexpensive methodology for the synthesized compounds. New some interesting heterocycles were synthesized by the reaction of 3-(4-bromo benzoyl)prop-2-enoic acid precursors with ethyl cyano acetate,malononitrile in different condition,acetyl acetone. Synthesis a various substituted pyridines derivatives incorporated with pyrimidine 12,13 and furan 15,17 precursors to enhance their biological activity .Finally, given the structures by spectral data (IR,H-NMR,MS

\section{Experimental}

All melting points are uncorrected. Elemental analyses were carried out in the Microanalytical Center, the center publication for research, Cairo, Egypt. By Elementar Viro El Microanalysis IR spectra $(\mathrm{KBr})$ were recorded on infrared spectrometer ST-IR DOMEM Hartman Braun, Model: MBB 157, Canada and H-NMR spectra recorded on a varian 300 MHz (Germany 1999) using TMS as internal standard. The mass spectra were recorded on Shimadzu GCMS-QP-1000 EX mass spectrometer at 70e.v. homogeneity of all compounds synthesized was checked by TLC.

\section{Ethyl-2-amino-4-carboxy-6-(4-bromo phenyl) nicotinate}

(2)

A solution of $\mathbf{1}(2.5 \mathrm{~g}, 0.01 \mathrm{~mol})$ and $3 \mathrm{~mL}$ ethylcyanoacetate and $5 \mathrm{~g}$ ammonium acetate was heated in water bath for $3 \mathrm{~h}$, then poured water the solid that separated with crystallized form ethanol afford 2. M.wt $365\left(\mathrm{C}_{15} \mathrm{H}_{13} \mathrm{BrN}_{2} \mathrm{O}_{4}\right)$ (m.p. $115^{\circ} \mathrm{C}$, yield $54 \%, \%$ calcd/found $[\mathrm{C} 49.30 / 49.22, \% \mathrm{H}$ $3.5 / 3.46, \%$ N 7.67/7.66, \% Br 21.9/21.6]. IR NH.3437, $\mathrm{C}=\mathrm{O}$ (acid and ester) 1686,1733, C=N $1620 \mathrm{~cm}-1{ }^{1} \mathrm{HNMR} 1.3(\mathrm{t}$, $3 \mathrm{H}, \mathrm{J}=7.4), 3.9\left(\mathrm{~s}, 2 \mathrm{H}, \mathrm{NH}_{2}\right), 4.05(\mathrm{q}, 2 \mathrm{H}, \mathrm{J}=7.4), 7.57 .8(\mathrm{~m}$, $5 \mathrm{H}, \mathrm{ArH}), 11.1(\mathrm{~s}, 1 \mathrm{H}, \mathrm{COOH})$. The EI-MS shows the molecular ion peak at $\mathrm{m} / \mathrm{e} 366$ and 364 corresponding to $(\mathrm{M}+2)^{+}\left(\mathrm{M}^{+}\right) \cdot$.respectively. 
3-cyano-4-carboxy-6-(4-bromo phenyl) 2(1H)-pyridones (3)

A solution of $1(2.5 \mathrm{~g}, 0.01 \mathrm{~mol})$ and $3 \mathrm{~mL}$ ethylcyanoace-tate and $5 \mathrm{~g}$ ammonium acetate was heated in water bath for $3 \mathrm{hs}$, then poured water the solid that separated was crystal-lized form Benzene -Ethanol afford 3 . M.wt $=319\left(\mathrm{C}_{13} \mathrm{H}_{7} \mathrm{BrN}_{2} \mathrm{O}_{3}\right) \quad$ (m.p $\quad 160^{\circ} \mathrm{C}$, yield $40 \%$, \% calcd/found[(C 48.92/ 48.94, H 2.19/2.18, N 8.78/8.81, Br 25.07/25.11 IR NH 3354, CN 2212, max of two carbonyl groups (cyclic amide and carboxyl group), 1655, 1678, and $\mathrm{C}=\mathrm{N} 1628,1 \mathrm{HNMR} 6.8-7.5(\mathrm{~m}, 5 \mathrm{H}, \mathrm{ArH}), 10.03(\mathrm{~s}, 1 \mathrm{H}, \mathrm{NH})$ $12.1(\mathrm{~s}, 1 \mathrm{H}, \mathrm{COOH})$. The EI-MS shows the molecular ion peak at $\mathrm{m} / \mathrm{e} 320$ and 318 corresponding to $(\mathrm{M}+2){ }^{+}$ $\left(\mathrm{M}^{+}\right)$.respectively.

2-amino-3-cyano-4-carboxy-6-(4-bromophenyl)-3,4-dihy dropyridine (4)

A solution of $1(2,5 \mathrm{~g}, 0.01 \mathrm{~mol})$ in n-butanol $(20 \mathrm{~mL})$ was treated with malononitrile $(0.7 \mathrm{~g}, 0.01 \mathrm{~mole})$ in $5 \mathrm{~g}$ ammonium acetate refluxed for $3 \mathrm{~h}$, then poured water with heating to replaceable n-butanol by water, then take the filtrate with ice/ $\mathrm{HCl}$. The solid that separated on cooling was crystallized form ethanol afford 4.M.wt $=320\left(\mathrm{C}_{13} \mathrm{H}_{10} \mathrm{BrN}_{3} \mathrm{O}_{2}\right)$ m.p. $220^{\circ} \mathrm{C}$, yield $75 \%$ calcd/found[(C48. 75/49.00, H 3.13/3.22, N 13.12/13.02, $\mathrm{Br} 25.00 / 25.08]$ IR $\mathrm{OH}, \mathrm{NH}, \mathrm{CN}, \mathrm{C}=\mathrm{O}$ at 3422 , 3220, 2211, $1707 \mathrm{~cm}-1{ }^{1} \mathrm{HNMR} 2.4(\mathrm{~s}, 2 \mathrm{H}, \mathrm{NH} 2), 2.8(\mathrm{~d}, 1 \mathrm{H}$, CHCN, J=8.5), 3.2(dd, $1 \mathrm{H}, \mathrm{CHCO} .5, \mathrm{~J}=8.5, \mathrm{~J}=6.4), 5.6(\mathrm{~d}$, $1 \mathrm{H}, \mathrm{H}-5$ pyr, $\mathrm{J}=6.4) 7.4-7.5(\mathrm{~m}, 4 \mathrm{H}, \operatorname{Ar}-\mathrm{H}), 11.03(\mathrm{~s}, 1 \mathrm{H}$, exchangeable proton The EI-MS shows the molecular ion peak at $\mathrm{m} / \mathrm{e} 321$ and 319 corresponding to $(\mathrm{M}+2)^{++}\left(\mathrm{M}^{+}\right)$. respectively

2-amino-3-cyano-4-carboxy-6-(4-bromophenyl)pyran(5)

A solution of $1(2.5 \mathrm{~g}, 0.01 \mathrm{~mol})$ in ethanol $(100 \mathrm{~mL})$ was treated with malononitrile $(0.7 \mathrm{~g}, 0.01 \mathrm{~mol})$ in piperidine $(2 \mathrm{~mL})$. Stirred at room temperature for $1 \mathrm{~h}$, then concentrated the solution and poured $\mathrm{H}_{2} \mathrm{O} / \mathrm{HCL}$. The solid that separated on cooling was crystallized form ethanol afford 5. M.wt= $321\left(\mathrm{C}_{13} \mathrm{H}_{9} \mathrm{BrN}_{2} \mathrm{O}_{3}\right)\left(\mathrm{m} . \mathrm{p} 121^{\circ} \mathrm{C}\right.$, yield $70 \%$, \% calcd/found [ $(\mathrm{C}$ 48.59/48.48, H 2.80/2.77, N 8.72/8.68, Br 24.92/25.81 IR $\mathrm{NH}$ (bonded and non bonded), 3227, 2339, $\mathrm{C}=\mathrm{O} 1705 \mathrm{~cm}-1$ and $\mathrm{C}=\mathrm{N} 1625,{ }^{1} \mathrm{HNMR} \quad 2.6(\mathrm{~s}, 2 \mathrm{H}, \mathrm{NH} 2), 2.8(\mathrm{~d}, 1 \mathrm{H}$, CH-CN),3,2(d,1H,CH-CO), 7.-7.5(m,5H,Ar-H),11.03(s, 1H, exchangeable proton). The EI-MS shows the molecular ion peak at $\mathrm{m} / \mathrm{e} 322$ and 320 corresponding to $(\mathrm{M}+2)^{+}$ $\left(\mathrm{M}^{+}\right)$.respectively

\section{4-(4-bromophenyl)-6-carboxy pyrimidin-2(1H)-thione} (6)

A solution of $1(2.5 \mathrm{~g}, 0.01 \mathrm{~mol})$ in $0.5 \mathrm{~g}$ sodium and $15 \mathrm{~mL}$ ethanol was treated with thiourea $(0,76 \mathrm{~g}, 0.01 \mathrm{~mol})$ refluxed for $4 \mathrm{~h}$. The solid that separated after cooling was crystallized form the suitable solvent afford 6 .M.wt $=311\left(\mathrm{C}_{11} \mathrm{H}_{7} \mathrm{Br} \mathrm{N}_{2} \mathrm{O}_{2}\right.$ $\mathrm{S})\left(\mathrm{m} . \mathrm{p} 200^{\circ} \mathrm{C}\right.$, yield $75 \%, \%$ calcd/found $[\mathrm{C} 42.44 / 42.48, \mathrm{H}$ 2.25/2.35,N 8.99/8.98,S 10.28/10.23, Br 25.72/25.61. IR $\mathrm{OH}$ and/or NH 3379, 3275, 3180 and $\mathrm{C}=\mathrm{O} 1676 \mathrm{C}=\mathrm{N}$ at $1613 \mathrm{~cm}-1,{ }^{1} \mathrm{HNMR}$ 3.9(s,1H,NH),6.4(s,1H,pyrimidine proton), 7.4(d,4H.Ar-H),11(s,1H,COOH). The EI-MS shows the molecular ion peak at $\mathrm{m} / \mathrm{e} 312$ and 310 corresponding to $(\mathrm{M}+2)^{+}\left(\mathrm{M}^{+}\right)$.respectively

\section{3-(4-bromophenyl)-5-carboxy-6-acetylcyclohexen-1-one} (7)

A solution of $1(2.5 \mathrm{~g}, 0.01 \mathrm{~mole})$ in $30 \mathrm{~mL}$ ethanol was treated with acetyl acetone $(0.01$ mole) refluxed in water bath for $4 \mathrm{~h}$, then poured water. The solid that separated on cooling was crystallized form the suitable solvent afford 7 . M.wt $=337\left(\mathrm{C}_{15} \mathrm{H}_{13} \mathrm{BrO}_{4}\right) \quad$ (m.p $119^{\circ} \mathrm{C}$, yield $75 \%$, \% calcd $/$ found[(C53.41/53.60, H 3.85/4.00, Br 23.72/23.72 IR exhibits $\mathrm{OH}=3430, \mathrm{CH}$ ar $=3030 \mathrm{CH}$ ali $=2888, \mathrm{C}=$ O1687,1695cm-1, ${ }^{1} \mathrm{HNMR} \quad 2.2\left(\mathrm{~s}, 3 \mathrm{H} . \mathrm{CH}_{3} \mathrm{CO}\right), 2.3(\mathrm{dd}, 2 \mathrm{H}$, diasteriotopic protons of allylic cyclohexanone), $2.9(\mathrm{~m}, 1 \mathrm{H}$, $\mathrm{CH}-\mathrm{COO}), 3.6(\mathrm{~d} \mathrm{~d}, 1 \mathrm{H}, \mathrm{CH}-\mathrm{CO}), 6.8-7.3(\mathrm{~m}, 5 \mathrm{H}, \mathrm{Ar}-\mathrm{H}), 11.3(\mathrm{~s}$, $1 \mathrm{H}, \mathrm{COOH})$. The EI-MS spectrum that the $\mathrm{m} / \mathrm{e} 319,317$ $\left(\mathrm{M}^{+}-\mathrm{H}_{2} \mathrm{O}\right)$.

\section{1-methyl 4,5-dihydro-6-(4-bromo phenyl) 8-hydrazino} phthalazin-4(3H)-one (8)

A solution of $(3.4 \mathrm{~g}, 0.01 \mathrm{~mol})$ in $50 \mathrm{~mL}$ ethanol was treated with hydrazine hydrae $(0.01$ mole) refluxed in for $3 \mathrm{~h}$, then heated to concentrate. The solid that separated after cooling was crystallized form the suitable solvent afford 8 . M.wt $=347\left(\mathrm{C}_{15} \mathrm{H}_{15} \quad \mathrm{Br} \mathrm{N}_{4} \mathrm{O} \quad\right.$ (m.p $280^{\circ} \mathrm{C}$, yield $55 \%$, \% calcd/found[(C 51.87/51.60,H 4.32/4.30,N 16.13/16.11 Br 23.05/23.12 IR (N H, 32003262 bonded and nonbonded $\mathrm{C}=\mathrm{O} 1657 \mathrm{~cm}-1 .{ }^{1} \mathrm{HNMR} \quad 0.9(\mathrm{~S}, 3 \mathrm{H}, \mathrm{CH} 3), 2.1(\mathrm{~s}, 2 \mathrm{H}, \mathrm{N}=\mathrm{NH} 2)$, 2.5(d,2H,allylic, $\mathrm{J}=8.7$ ), 3.1 (dt,1 $\mathrm{Hb}$, fused ring, $\mathrm{J}=8.7, \mathrm{~J}=9.2$ ), 3.5(d,1Ha,fused-ring J=9.2), $6.4(\mathrm{~s}, 1 \mathrm{H}$,olefin proton), 7.27.4 (dd,4H,ArH), 11(s,1H,NH). EI-MS exhibits molecular ion peak $\mathrm{m} / \mathrm{e}(348,18.2 \%)$ beside some of abundant peaks.

3- methyl 6(4-bromo phenyl)2,3-dihydro-1,2- benzoxazole-4-carboxylic acid (9)

A solution of $7(3.4 \mathrm{~g}, 0.01 \mathrm{~mol})$ in $20 \mathrm{~mL}$ pyridine was treated with hydroxylamine $(0.01$ mole $)$ refluxed for $3 \mathrm{hs}$, then poured ice $/ \mathrm{H}_{2} \mathrm{O}$. The solid that separated after cooling was crystallized form Benzene to afford 9. M.wt $=336\left(\mathrm{C}_{15} \mathrm{H}_{14}\right.$ $\mathrm{Br} \mathrm{NO}_{3} \quad$ (m.p $166^{\circ} \mathrm{C}$, yield $55 \%$ ，\% calcd/found $[(\mathrm{C}$ 53.57/53.60,H 4.16/4.20,N 4.16/4.21 Br 23.81/23.77 IR (OH 3250 (saturatedacid), $\mathrm{C}=\mathrm{O}, 1700, \mathrm{C}=\mathrm{N} 1618 \mathrm{~cm} .{ }^{1} \mathrm{HNMR} 1.2$ $(\mathrm{d}, 3 \mathrm{H}, \mathrm{CH} 3, \mathrm{~J}=7.5) 2.1(\mathrm{~s}, 2 \mathrm{H}, \mathrm{N}=), 2.3(\mathrm{dd}, 2 \mathrm{H}, \mathrm{CH} 2$ diasteriotopicprotons $\mathrm{J}=14.2, \mathrm{~J}=4.3 \& \mathrm{~J}=9.4, \mathrm{~J}=4.3), 2.9(\mathrm{dd}, 1 \mathrm{H}$, CHCOO, $\mathrm{J}=14.2, \mathrm{~J}=9.4), 4(\mathrm{q}, 1 \mathrm{H}, \mathrm{CH}-\mathrm{N}, \mathrm{J}=7.5), 7.27 .5(\mathrm{~m}, 5 \mathrm{H}$, $\mathrm{ArH}), 8.2(\mathrm{~s}, 1 \mathrm{H}, \mathrm{NH}), 11(\mathrm{~s}, 1 \mathrm{H}, \mathrm{COOH})$. The EI-MS shows the molecular ion peak at $\mathrm{m} / \mathrm{e} 337$ and 335 corresponding to $(\mathrm{M}+2)^{+}\left(\mathrm{M}^{+}\right) \cdot$ respectively

6-(4-bromo

phenyl)-3-cyano-2-(ethoxymethyleneamino)-pyridine-4carboxylic acid (11)

Pyridine derivative $4(3.2 \mathrm{~g}, 0.01 \mathrm{~mol})$ in $(0.35 \mathrm{~mL}$, $0.01 \mathrm{~mol}$ triethylorthoformate was stirred under reflux for $5 \mathrm{~h}$. The reaction mixture was concentrated and the obtained brown precipitate then crystallized from ethanol/water to afford ethoxy methylene amino pyridine 11. M.wt=376 $\left(\mathrm{C}_{16} \mathrm{H}_{13} \mathrm{BrN}_{2} \mathrm{O}_{4}\right.$ (m.p $175^{\circ} \mathrm{C}$, yield $75 \%$, \% calcd/found [(C51.07/51.09, H 4.16/4.20,N 7.44/7.41 Br 21.27/21.27 IR (OH3350(saturated acid), $\mathrm{CN} 2200 \mathrm{C}=\mathrm{O}, 1718, \mathrm{C}=\mathrm{N} 1628 \mathrm{~cm}$ ${ }^{1} \mathrm{HNMR} 1.33$ (t, 3H, OCH2CH3, J=7.6), 2.7(d, 1H, CHCN $\mathrm{J}=8.5), \quad 3.1(\mathrm{dd}, 1 \mathrm{H}, \mathrm{CHCO}, \mathrm{J}=8.5, \mathrm{~J}=6.4) \quad 4.29(\mathrm{q}, 2 \mathrm{H}, \mathrm{OCH} 2$, $\mathrm{J}=7.6), 5.16(\mathrm{~d}, 1 \mathrm{H}, \mathrm{J}=6.4 \mathrm{H}-5 \mathrm{Pyr}), 7.5-7.7(\mathrm{~m}, 4 \mathrm{H}, \operatorname{ArH})-$ 
8.2( $(\mathrm{s}, 1 \mathrm{H}, \mathrm{N}=\mathrm{CH}), 11.5(\mathrm{~s}, 1 \mathrm{H}, \mathrm{OH}$, exchangeable proton $)$ The EI-MS shows the molecular ion peak at $\mathrm{m} / \mathrm{e} 377$ and 375 corresponding to $(\mathrm{M}+2)^{+}\left(\mathrm{M}^{+}\right)$.respectively

4-amino-7-(4-bromophenyl)-5H-pyridino[2,3-d]pyrimidi ne-5-carboxylic acid (12a)

A solution of ethoxy methylene amino-4H-pyridine 11 $(3.8 \mathrm{~g}, 0.01 \mathrm{~mol})$ and absolute ethanol $(10 \mathrm{~mL})$,ammonia solution $(0.015 \mathrm{~mL}, 0.01 \mathrm{~mol})$ was added. The resulting mixture was refluxed for $2 \mathrm{~h}$.After cooling, the reaction mixture was acidified with very diluted solution of cold $\mathrm{HCl}$, the precipitate formed was formed was filtered off and washed on the filter funnel with water,dried then crystallized from ethanol/water to afford the amino pyrido-pyrimidine(12) M.wt $=347\left(\mathrm{C}_{14} \mathrm{H}_{10} \mathrm{BrN}_{3} \mathrm{O}_{3}\right.$ (m.p $140^{\circ} \mathrm{C}$, yield $85 \%$, \% calcd $/$ found $[(\mathrm{C} 48.41 / 48.60, \mathrm{H} 2.88 / 2.80, \mathrm{~N}$ 12.10/12.21 $\mathrm{Br} 23.05 /$ $23.12 \mathrm{IR},\left(\mathrm{OH}(\mathrm{NH}) 3359, \mathrm{C}=\mathrm{O}, 1730, \mathrm{C}=\mathrm{N} 1648 \mathrm{~cm} .{ }^{1} \mathrm{HNMR}\right.$, $2.9(\mathrm{~d}, 1 \mathrm{H}, \mathrm{CHC}-\mathrm{NH} 2 \mathrm{~J}=8.1), 3.1(\mathrm{dd}, 1 \mathrm{H}, \mathrm{CHCO}, \mathrm{J}=8.1, \mathrm{~J}=6.4)$ 5.2(d,1H.H-5pyr,J=6.4), 7.3(s,2H,exchangeable NH2), 7.6$7.5(\mathrm{~m}, 4 \mathrm{H}, \mathrm{ArH}) \quad 9.2(\mathrm{~s}, 1 \mathrm{H}, \mathrm{CH}$,pyrimidine $), 11.45(\mathrm{~S}, 1 \mathrm{H}$, exchangeable $\mathrm{OH}$ The EI-MS shows the molecular ion peak at $\mathrm{m} / \mathrm{e} 348$ and 346 corresponding to $(\mathrm{M}+2)^{+}\left(\mathrm{M}^{+}\right)$.respectively 5-(4-bromophenyl)-1,2,3a-trihydro-6-oxa-1,2,,7,9-tetrap henalen-3(3H)-one (13)

A mixture of $11(3.8 \mathrm{~g}, 0.01 \mathrm{~mol})$ and hydrazine hydrate [34] $(0.012 \mathrm{~mL}, 0.01 \mathrm{~mol})$ in absolute ethanol $(30 \mathrm{ml})$ was refluxed for $7 \mathrm{~h}$. The reaction mixture was left to cool at r.t.then acidified with diluted $\mathrm{HCl}$, the formed solid was filtered off, washed with cold water, dried and crystallized from the proper solvent to afford pyridopyrimidine(13) $\mathrm{M} . \mathrm{wt}=344$ $\left(\mathrm{C}_{14} \mathrm{H}_{12} \mathrm{Br} \mathrm{N}_{4} \mathrm{O}_{2}\right.$ (m.p $136^{\circ} \mathrm{C}$, yield $85 \%$, \% calcd/found[ $(\mathrm{C}$ 48.83/48.62,H 3.48/3.51 ,N16.26/16.21, Br23.25/23.27. IR(NH3320, $\mathrm{C}=\mathrm{O} 1650, \mathrm{C}=\mathrm{N} 1615 \mathrm{~cm}$.

${ }^{1} \mathrm{HNMR}, 2.3(\mathrm{~d}, 1 \mathrm{H}, \mathrm{CHC}-\mathrm{NH} \mathrm{J}=8.5), 3.1(\mathrm{dd}, 1 \mathrm{H}, \mathrm{CHCO}$, $\mathrm{J}=8.5, \mathrm{~J}=6.4), \quad 4.3(\mathrm{~s}, 1 \mathrm{H}, \mathrm{CONH}(\mathrm{NH})$ exchangeable $), 4.9(\mathrm{~d}$, $1 \mathrm{H}, \mathrm{H}-5$ pyr, J=6.4), 7.2-7.5(m, 4H, ArH)8.7(s, 1H, CONH), 9.4(s,1H,CH pyrimidine). The EI-MS shows the molecular ion peak at $\mathrm{m} / \mathrm{e} 345$ and 343 corresponding to $(\mathrm{M}+2)^{+}$ $\left(\mathrm{M}^{+}\right)$.respectively

2-(3-carboxy acrylamido)-6-(4-bromo phenyl)-3- cyanopyridine-4-carboxylic acid (14)

Maleic anhydride $(0.98 \mathrm{mg}, 0.01 \mathrm{~mol})$ was completely dissolved at room temperature in glacial acetic acid or THF $(10 \mathrm{~mL})$, and then pyridine derivative $4(3.2 \mathrm{~g}, 0.01 \mathrm{~mol})$ was added to the solution; the resulting mixture was stirred under reflux for $1 \mathrm{~h}$. The reaction mixture was allowed to cool at room temperature, then poured into water $(20 \mathrm{ml})$, the precipitate formed was filtered off, washed with water,dried and crystallized from methanol to afford $\mathrm{N}$-substituted maleamic acid 14. M.wt $=416\left(\mathrm{C}_{17} \mathrm{H}_{10} \quad \mathrm{Br} \mathrm{N}_{3} \mathrm{O}_{5}\right.$ (m.p $166^{\circ} \mathrm{C}$, yield $55 \%$ \% \% calcd/found[(C 49.04/49.20,H 2.40/2.45,N 10.09/ 10.09 Br 19.23/19.37 IR, (OH and/or NH 3450-3372- 3225, $\mathrm{CN} 2210, \mathrm{C}=\mathrm{O}, 1720, \mathrm{C}=\mathrm{O}$ amide $1648 \mathrm{~cm} .{ }^{1} \mathrm{HNMR}$ 2.2.9(d,1H,CHCN J=8.5), 3.1(dd, $1 \mathrm{H}, \mathrm{CHCO}, \mathrm{J}=8.5, \mathrm{~J}=6.4)$ $5.4(\mathrm{~d}, 1 \mathrm{H}, \mathrm{H} 5-\mathrm{pyr}, \mathrm{J}=6.4) 6.6(\mathrm{~d}, 1 \mathrm{H}, \mathrm{J}=15.3, \mathrm{CH}=), 7.15$ $(\mathrm{d}, 1 \mathrm{H}, \mathrm{J}=15.3,=\mathrm{CH}) 7.57 .7(\mathrm{~m}, 4 \mathrm{H}, \mathrm{ArH}) 10.2(\mathrm{~S}, 1 \mathrm{H}, \mathrm{NHCO})$, $11.7(\mathrm{~s}, 1 \mathrm{H}$,exchangeable $\mathrm{OH}), 12.3(\mathrm{brs}, 1 \mathrm{H}, \mathrm{COOH})$. The EIMS shows the molecular ion peak at m/e 317 and 315 cor- responding to $(\mathrm{M}+2)^{+}\left(\mathrm{M}^{+}\right)$.respectively

2-[5-amino-3-(carboxymetbyl)-4-cyanofuran- 2- ylamino 1-6-(4-bromophenyl)-3-cyano pyridine-4-carboxylic acid (15)

To a solution of -cyclic maleamic acid $14(2.00 \mathrm{~g}, 5.2$ $\mathrm{mmol})$ and malononitrile $(0.34 \mathrm{~g}, 5.2 \mathrm{mmol})$ in DMF $(4 \mathrm{~mL})$ few drops of piperidine was added; the resulting mixture was refluxed at $60 \mathrm{C}$ for $5 \mathrm{~h}$. The reaction mixture was allowed to cool at room temperature then acidified with diluted acetic acid $20 \mathrm{~mL}$, the solid formed was filtered off, washed with water, dried and crystallized from methanol/water to afford furan derivative $15 \mathrm{M} . \mathrm{wt}=482\left(\mathrm{C}_{20} \mathrm{H}_{12} \mathrm{Br} \mathrm{N}_{5} \mathrm{O}_{5}\right.$ (m.p $166^{\circ} \mathrm{C}$, yield $75 \%, \%$ calcd/fou[(C 49.79/49.60, H 2.48/2.40, N 14.52/14.41 $\mathrm{Br} 16.59 / 16.77 \mathrm{IR}(\mathrm{OH}$ and/or NH) 3250,3370, 3445., CN 2210., $\mathrm{C}=\mathrm{O}, 1720, \mathrm{C}=\mathrm{N} 1628 \mathrm{~cm} .{ }^{1} \mathrm{HNMR} 2.9(\mathrm{~d}$, $1 \mathrm{H}, \mathrm{CHCN} \mathrm{J}=8.5), 3.1(\mathrm{dd}, 1 \mathrm{H}, \mathrm{CHCO}, \mathrm{J}=8.5, \mathrm{~J}=6.4) 3.83(\mathrm{~s}$, $2 \mathrm{H}, \mathrm{CH} 2)$ 5.9(d, $1 \mathrm{H}, \mathrm{H}-5 \mathrm{pyr}, \mathrm{J}=6.4), 7.2-7.5(\mathrm{~m}, 4 \mathrm{H}, \mathrm{ArH})$, $8.2(\mathrm{~S}, 2 \mathrm{H}, \mathrm{NH} 2), 10.5(\mathrm{~s}, 1 \mathrm{H}$, exchangeableNH) 12.3 (brs, $1 \mathrm{H}$, $\mathrm{COOH})$. The EI-MS shows the molecular ion peak at $\mathrm{m} / \mathrm{e}$ 483 and 481 corresponding to $(\mathrm{M}+2)^{+}\left(\mathrm{M}^{+}\right)$.respectively

2-[5-amino-3-(carboxymethyl)-4-cyano-lH-pyrrol-2-yla mino)]-6(4-bromophenyl)-3-cyanopyridine-4-carboxylic acid (16)

A mixture ofN-cyclic maleamic acid $14(2 \mathrm{~g}, 5.2 \mathrm{mmol})$ and malononitrile[36] $(0.34 \mathrm{~g}, 5.2 \mathrm{mmol})$ in DMF $(3 \mathrm{~mL})$ in the presence of ammonium acetate was refluxed at $60 \mathrm{C}$ for 3 $\mathrm{h}$. The reaction mixture was allowed to cool at room temperature then poured into diluted solution of acetic acid 20 $\mathrm{ml}$, the solid formed was filtered off, washed with water, dried and crystallized from ethanol/water to afford aminopyrrole derivative $16 \mathrm{M} . \mathrm{wt}=481\left(\mathrm{C}_{20} \mathrm{H}_{13} \mathrm{BrN}_{6} \mathrm{O}_{4}\right.$ (m.p $166^{\circ} \mathrm{C}$, yield $75 \%, \%$ calcd/found[(C 49.81/49.70,H 2.70/2.64,N $17.46 / 17.41 \mathrm{Br} 16.59 / 16.77 \mathrm{IR}(\mathrm{OH}$ and/ or $\mathrm{NH}) 3250,3350$, $3440, \mathrm{CN} 2218, \mathrm{C}=\mathrm{O}, 1720, \mathrm{C}=\mathrm{N} 1628 \mathrm{~cm} .{ }^{1} \mathrm{HNMR} 2.8(\mathrm{~d}$, $1 \mathrm{H}, \mathrm{CHCN} \mathrm{J}=8.5$ ), 3.2(dd, 1H, CHCO, J=8.5, J=6.4) 3.8(s, $2 \mathrm{H}, \mathrm{CH} 2), 5.2(\mathrm{~d}, 1 \mathrm{H}, \mathrm{H}-5 \mathrm{pyr}) 7.2-7.5(\mathrm{~m}, 4 \mathrm{H}, \mathrm{ArH}) 8.4(\mathrm{~s}$, $1 \mathrm{H}$,exchangeable $\mathrm{NH}), 11.8(\mathrm{~s}, 1 \mathrm{H}$, exchangeable $\mathrm{NH} 12.3(\mathrm{~s}$, $1 \mathrm{H}, \mathrm{COOH})$. The EI-MS shows the molecular ion peak at $\mathrm{m} / \mathrm{e}$ 482 and 480 corresponding to $(\mathrm{M}+2)^{++}\left(\mathrm{M}^{+}\right)$.respectively 2-[4-acetyl-3-(carboxymetbyl)-5-methylf uran-2-ylamino 1-6-(4-bromo phenyl)-3-cyanopyridine-4-carboxylic acid (17)

A mixture of N-cyclic maleamic acid $14(2 \mathrm{~g}, 5.2 \mathrm{mmol})$ and acetylacetone $(0.53 \mathrm{~mL}, 5.2 \mathrm{mmol})$ in DMF $(3 \mathrm{~mL})$ in the presence of piperidine was refluxed at $60 \mathrm{C}$ for $3 \mathrm{~h}$. The reaction mixture was allowed to cool at room temperature then poured into diluted solution of acetic acid $(200 \mathrm{~mL})$, the solid formed was filtered off, washed with water, dried and crystallized from ethanol/ water to afford furan derivatives 17. M.wt $=498\left(\mathrm{C}_{22} \mathrm{H}_{16} \mathrm{Br} \mathrm{N}_{3} \mathrm{O}_{6}\right.$ (m.p $166^{\circ} \mathrm{C}$, yield $55 \%$, \% calcd/found[(C53.01/53.20,H $3.21 / 3.20, \mathrm{~N} \quad 8.43 / 8.61 \mathrm{Br}$ 16.06/16.21 IR(OHand/orNH) 3250,3330,3515. CN 2208, $\mathrm{C}=\mathrm{O}, 1720, \mathrm{C}=\mathrm{N} 1620 \mathrm{~cm} .{ }^{1} \mathrm{HNMR} 2.6(\mathrm{~s}, 3 \mathrm{H}, \mathrm{OCH} 3) 2.9(\mathrm{~d}, 1 \mathrm{H}$, CHCN J=8.5), 3.1(dd, $1 \mathrm{H}, \mathrm{CHCO}, \mathrm{J}=8.5, \mathrm{~J}=6.5), 3.8(\mathrm{~s}, 2 \mathrm{H}$, $\left.\mathrm{CH}_{2}\right), 5.6(\mathrm{~d}, 1 \mathrm{H}, \mathrm{H}-5$ pyr J=6.5), 7.2-7.5(m,4H,ArH), 8.2(s, $\left.2 \mathrm{H}, \mathrm{NH}_{2}\right), 10.6(\mathrm{brs}, 1 \mathrm{H}$, exchangeable $\mathrm{OH}), 12.2(\mathrm{~s}, 1 \mathrm{H}$, $\mathrm{COOH})$. El-MS exhibited $\mathrm{m} / \mathrm{z} 454$ and 452 corresponding to 
$\left([\mathrm{M}+2]\right.$ and $\left.\mathrm{M}-\mathrm{CO}_{2}\right)$ respectively.

\section{ACKNOWLEDGMENTS}

Thanks for god to complete this research, the authors grateful to your collage in organic lab, Ain shams university and micro analytical data in Cairo University for providing facilities to carry out the research work.

\section{REFERENCES}

[1] Koehler,T.; Friedrich,G.; and Nmhu,P.: Agents Actions,,32 (1-2), 70; C.A-115, 88049z. (1991)

[2] Koehler,T.; Kirchner,H.M.; Peinhard,G,; Hirsch-elmann,R.; and Nmhu,P.: Biochem, Pharmacol,,44 (4) 805; C.A. 117, 204766Y, (1992).

[3] Bowden,K.; Daplozzo,A.; and Duah,C.K. J. Chem. Res, Synap, (1990)

[4] Thomas,J.C.: U.S. 1950,2, 532, 579,: C.A.45, 1290, (1951).

[5] Juranic,Z.,. Stevovic,L.J, Drakulo,D.; Stanojkovic,T.; Radulovic,S.J.Serb. Chem. Soc., 64, 505, (1999)

[6] Sameh. A. Rizk, Maher.A.EL-Hashash and Moktar. M. Aburzeza; Utility of p-Acetamidobenzoyl Prop-2enoic Acid in the Synthesis of New $\alpha$-Amino Acids and Using them as Building Blocks in Heterocyclic Synthesis Egypt. J.Chem. $54,3,2011$

[7] A.M.F.Eissa J.Chinase, 52,(1205-1214),.(2005)

[8] El-Hashash, M. A. Abd El-Mageid, G. A. El-Kady, S. S. Mohammed S. A;Egypt J.Chem.51(1),103-112 (2008)

[9] Rizk,S.A;El-Hashash,M.A.;Mostafa,K.K.; Utility of $\beta$-Aroyl Acrylic acid in Heterocyclic Synthesis. Egypt, J. Chem. 51 (5) 116-121 (2008)

[10] Elha-

shash,M.;A.Soliman;M.Madkour,RevueRoumainedeChimie, ,38(8),955 (1993)

[11] El-Hashash,M;Amine,M.;SolimanF.;Morsi,MJ.Serb.Chem.S oc.57(9),563(1992)

[12] Youssef.A.Madkour,H.;MarzoukM.;El-Hashash;M.ElSollA.,Can. J.Chem. 83,251 (2005)

[13] S.A.Rizk , M.A.El-Hashash , M.M.Aburzeza ; 1,4-Arylation of $\beta$-(4-acetylaminobenzoyl)acrylic Acid with Activated Aromatic Hydrocarbons under Fridel-Crafts Conditions and Some Studies with the Products.Egypt.J.Chem.54,1,(2011)

[14] Yous-

sef,A.S.;Madkour,H.F.;Marzouk,M.I.;El-Soll,A.M.;El-Hasha sh, M.A.;Utility of 3-Aroyl prop-2-enoic acid in Heterocyclic Synthesis.Afinidad,61(512),304-316 (2003)

[15] Sondhi, S. M.; Johar, M.; Rajvanshi, S.; Dastidar, S. G.;
Shukla, R.; Raghubir, R.; Lown, J.W. Australian J. Chem., 54, 69. (2001)El-Gaby, E. A.; Abdel-Hamide, S. G.;)

[16] Ghorab, M. M.; El-Sayed, S. M. Acta Pharm. 49, 149.(1999. Devries, E. G. E.;

[17] Gietma, J. A.; Workman, P.; Scott, J. E.; Crawshaw, A.; Dobbis, H. J.;Dennis, I.; Mulder, N.; Sleijfer, D. T. H.; Willemse, P. H. B. Br. J. Cancer. 68, 661.(1993)

[18] Nasr, M. N.; Gineinah, M. M. Arch. Pharm., 335, 289. (2002)

[19] Cammito, A.; Pemmisin, M.; Lnu-Due, C.; Hoguet, F.; Gaultier, C.; Narcisse, J. Eur. J.Chem., 25, 635. (1990)

[20] Pemmisin, M.; Lue-Due, C.; Hoguet, F.; Gaultier, C.; Narcisse, J. Eur. J. Chem., 23,534. (1988)

[21] Smith, P. A. S., Kan, R. O. J. Org. Chem. 29, 2261.(1964)

[22] Nega, S.; Aionso, J.; Diazj, A.; Junquere, F. J. Heterocyclic Chem., 27, 269 (1990)

[23] Kuyper, L. F.; Baccanari, D. P.; Jones, M.L.; Hunter, R.N.; Tansik, R. L.; Joyner, S. S.;Boytos, C. M.; Rudolph, S. K.; Knick, V.; Wilson, H. R.; Caddell, J. M.; Friedman, H. S.;Comley J. C. W.; Stables, J. N. J. Med. Chem., 39, 892. (1996)

[24] Hunger, A.; Hoffmann, K. Helv. Chim. Acta, 40, 1319. (1957)

[25] Ismagilva, A. F.; Zarudy, F. S.; Lazareva, D. N.; Davydova, V. A.; Karachuria, L. T.;Ismagilova, Z. F.; Tropynina, Y. G. Antibiot. Khimioter. 43, 19. Chem. Abst.,129, 76035t. (1998)

[26] Srivastava, V.; Negi, A. S.; Kumar, J. K.; Faridi, U.; Sisodia, B.S.; Darokar, M. P.; LuqmanS.; Khanuja, S. P. S. Bioorg. Med. Chem. Lett., 16, 911. (2006)

[27] Toshio, O.; Yoshikazu, S.; Yoshimi, A.; Yasuhiro, I.; Tamotsu, F.; Noriko, S.; Yuji, Y.;Tetsuji, A.; Toshikazu, O. J. Antibiot., 53, 337. (2000)

[28] Jeffrey, D. P. Joan, D.A.; Edward, W.J. PCT Int. Appl., 97. (1999)

[29] Treek,T.;Vereek,B.ARKIVOC,14,96 (2005)

[30] Booth,B.L.;Costa,F.A.T.;Mahmood,Z.;Pritchard,R.G.;Proen ca,N.F. J.Chem,Soc.Perkin Trans 1.,1853(1999)

[31] Al-Afaleq,E.I Synth.Commun.31,2557 (2001)

[32] Dave,C.G.;Shah,R.D.Molecules,7,554 (2002)

[33] James ,B.M.; Richard, W..Biochemistry..7.3453(1968).

[34] Loakes D; Browna, D.M..; Salisbury, S.A... J.Chem.Soc., Perkin Trans.1, 1333(1999).

[35] Subbotina,J.O.;Fabian,W.M.F.;Tarasov,E.V..;Volkova,N.N.; Bakule V.A..Eur.J.Org. Chem.,2914.(2005)

[36] Rich ,D.;Gesellchen,P.;Tong,A. Cheung ,Al.; Buckner,C. J.Med.Chem, 18,1004,(1975).

[37] Bhatt,M. i;Ali,S.; Huma,F.; Shahzadi,S.Turk.J.Chem.29,463, (2005)

[38] Wang,X.S.;Shi,D.Q.;Tu,S.J.Synth. Commun,32,3449,(2002) 